\title{
Quarterly Report on the Strontium Heat Source Development Program, Advanced Nuclear Systems and Projects Division for June-September 1980
}

H. T. Fullam

February 1981

Prepared for the U.S. Department of Energy under Contract DE-AC06-76RLO 1830

Pacific Northwest Laboratory Operated for the U.S. Department of Energy by Battelle Memorial Institute 
This report was prepared as an account of work sponsored by the United States Government. Neithet the Linted States nor the Department of Energy, nor any of their employees, nor any of their contractors, subcontractors; or theur employees, makes any warranty, express or implied, or assumes any legal liability of responsibility for the accuracy. completeness or usetulness of any information, apparatus, product or process disclosed. or represents that its use would not infringe privately owned tights.

The views, opinions and conclusions contained in this report are those of the contractor and do not necessarily represent those of the United States Government or the Unued States Department of Energy

\author{
PACIFIC NORTHWEST LABORATORY \\ operated by \\ BATTELLE \\ for the \\ UNITED STATES DEPARTMENT OF ENERCY \\ Under Contract DE-AC06-76RLO 1830
}

\author{
Prinied in the United States of Ametica \\ Available trom \\ Vational Technical information Service \\ United States Department of Commerce \\ 5285 Part Royal Road \\ Springtieid, Virginis 22151
}

Price: Prinied Copy 3

$\therefore$ Microfiche $\$ 3.00$

NTIS

-Pages Selling Price

$\begin{array}{ll}001-025 & 54.00 \\ 026-050 & 54.50 \\ 051-075 & 55.25 \\ 076-100 & 56.00 \\ 101-125 & 56.50 \\ 126-150 & 57.25 \\ 151-175 & 58.00 \\ 176-200 & 59.00 \\ 391 \cdot 225 & 59.25 \\ 226-250 & 59.50 \\ 251-273 & 510.75 \\ 276-300 & 511.00\end{array}$


QUARTERLY REPORT ON THE STRONTIUM HEAT SOURCE DEVELOPMENT PROGRAM, ADVANCED NUCLEAR SYSTEMS AND PROJECTS DIVISION FOR JUNE-SEPTEMBER 1980

H. T. Fullam

February 1981

Prepared for the U.S. Department of Energy under Contract DE-ACO6-76RLO 1830

Pacific Northwest Laboratory

Richland, Washington 99352 

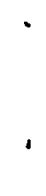

$\star$ 
Hastelloy S and Hastelloy C-4 subsize Charpy V-Notch (CVN) specimens that had been heated in air or vacuum at $600^{\circ}, 700^{\circ}$, or $800^{\circ} \mathrm{C}$ for up to $10,000 \mathrm{~h}$ were impact-tested at room temperature. No significant differences in Charpy impact energy were observed between the CVN specimens heated in air and the control specimens heated in vacuum. The CVN specimens aged at $600^{\circ} \mathrm{C}$ showed the greatest reduction in Charpy impact energy, while the specimens aged at $800^{\circ} \mathrm{C}$ showed the least change.

Qualification testing of the as-fabricated prototype outer capsules was completed. The capsules passed all of the qualification tests without difficulty. The capsules subjected to the impact (drop) test showed some distortion at the weld area but passed the helium leak test.

After the qualification tests were completed two of the capsules were subjected to additional external-pressure tests. The Hastelloy $S$ capsule was pressurized to 24,000 psi (the limit of the autoclave) and showed only a slight distortion. The Hastelloy $\mathrm{C}-4$ capsule collapsed at a pressure of 20,750 psi. Both capsules passed the helium leak check after pressurization. Two other capsules were subjected to an increased percussion test using an impact energy of $20 \mathrm{~kg}-\mathrm{m}$ instead of the $7 \mathrm{~kg}-\mathrm{m}$ used in the standard test. Both the Hastelloy $S$ and Hastelloy $\mathrm{C}-4$ capsules passed the more stringent test without difficulty. 


\section{CONTENTS}

\begin{tabular}{|c|c|c|c|c|c|c|c|c|c|c|c|}
\hline SUMMARY & - & - & - & - & - & - & - & - & . & • & \\
\hline STRONTIUM & HEAT & SOURCE & DEVELOPMENT & PROGRAM & - & . & . & . & . & • & \\
\hline TASK & $1-$ & CHEMICA & L AND PHYSICA & AL PROPERTI & ES OF & ${ }^{90}{ }_{S r F}$ & & & & 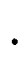 & \\
\hline TASK & $2-$ & ${ }^{90} \mathrm{SrF}_{2}$ & COMPATIBILITY & Y STUDIES & & . & . & . & • & • & \\
\hline TASK & $3-$ & CAPSULE & QUAL IF ICAT IO & ON AND LICE & NSING & . & . & . & • & • & \\
\hline & Char & py Impa & ict Energy of & Hastelloy & $S$ and & Haste & elloy & $C-4$ & • & ${ }^{\circ}$ & \\
\hline & Caps & ule Tes & ting & - & - & - & - & - & • & • & \\
\hline REFERENCES & & . & . & - & . & - & . & . & • & • & \\
\hline
\end{tabular}




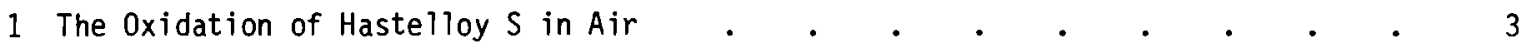

2 The Oxidation of Hastelloy C-4 in Air . . . . . . . . . . . . . . 3

3 The Room-Temperature Charpy Impact Energy of Hastelloy S Specimens Heated

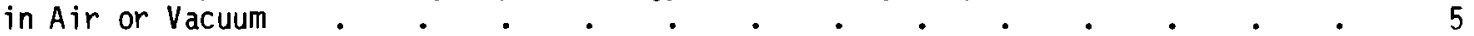

4 The Room-Temperature Charpy Impact Energy of Hastelloy C-4 Specimens Heated in Air or Vacuum .

5 Distortion of the As-Fabricated Hastelloy S Prototype Outer Capsule Resulting from the Impact Test $\quad . \quad \cdot \quad \cdot \quad \cdot \quad \cdot \quad \cdot \quad \cdot \quad \cdot \quad \cdot \quad \cdot \quad \cdot 7$

6 Distortion of the As-Fabricated Hastelloy C-4 Prototype Outer Capsule

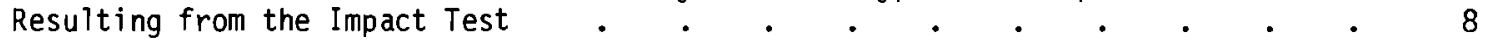

7 End Cap of the Hastelloy S Capsule After the Impact Test Showing the

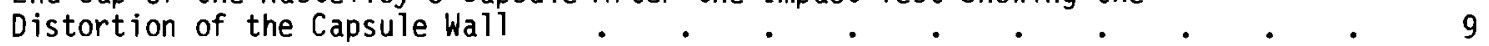

8 Weld Area of the Impacted Hastelloy S Capsule $\quad . \quad$. $\quad . \quad$. $\quad . \quad$. 10

9 End Cap of the Hastelloy C-4 Capsule After the Impact Test Showing the

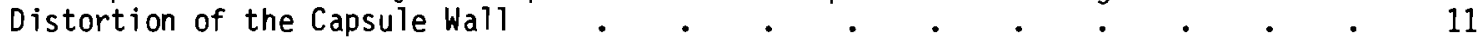

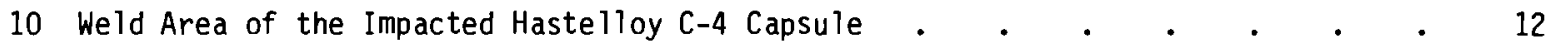

11 As-Fabricated Hastelloy C-4 Outer Capsule After Being Subjected to an External Hydrostatic Pressure of 20,700 psi . . . . . . . . . $\quad 13$

12 Dimensions of the As-Fabricated Hastelloy C-4 Capsule After Being Subjected to an External Hydrostatic Pressure of 20,750 psi . . . . . . . $\quad 14$

13 The Hastelloy C-276 Inner Capsule After Being Subjected to An External Hydrostatic Pressure of $9700 \mathrm{psi}$.

\section{TABLES}

1 0xidation of Hastelloy S and Hastelloy C-4 in Air . . . . . . . . . 2

2 Subsurface Attack of Hastelloy S and Hastelloy $\mathrm{C}-4$ Specimens 0xidized in Air at $600^{\circ}$ to $800^{\circ} \mathrm{C}$

3 The Room-Temperature Charpy Impact Energy of Hastelloy S and Hastelloy C-4 CVN Specimens Heated in Air or Vacuum 


\section{STRONTIUM HEAT SOURCE DEVELOPMENT PROGRAM}

H. H. Van Tuyl, Program Manager

H. T. Fullam, Principal Investigator

At hanford, strontium is separated from the high-level waste, converted to the fluoride, and doubly encapsulated in small, high-integrity containers for subsequent long-term storage. The fluoride conversion, encapsulation, and storage take place in the Waste Encapsulation and Storage Facilities (WESF). The encapsulated strontium fluoride represents an economical source of ${ }^{90} \mathrm{Sr}$ if the WESF capsule can be licensed for heat-source applications under anticipated-use conditions. The objectives of this program are to obtain the data needed to license ${ }^{90} \mathrm{SrF}_{2}$ heat sources and specifically the WESF ${ }^{90} \mathrm{SrF}_{2}$ capsules. The information needed for licensing can be divided into three general task areas:

Task 1 - Chemical and Physical Properties of ${ }^{90} \mathrm{SrF}_{2}$

Task $2-{ }^{90} \mathrm{SrF}_{2}$ Compatibility Studies

Task 3 - Capsule Qualification and Licensing.

Efforts are proceeding concurrently on all three tasks to obtain the required information.

$\underline{T A S K}_{1}$ - CHEMICAL AND PHYSICAL PROPERTIES OF ${ }^{90} \mathrm{SrF}_{2}$

No activity this quarter.

$\underline{\text { TASK } 2-{ }^{90} \mathrm{SrF}_{2} \text { COMPATIBILITY STUDIES }}$

Electron microprobe analysis of the metal specimens from the $30,000 \mathrm{~h}$ tests with ${ }^{90} \mathrm{SrF}_{2}$ has been completed by R. S. Crouse at Oak Ridge National Laboratory. This completes the last of the scheduled experimental activities relating to the compatibility of ${ }^{90} \mathrm{SrF}_{2}$ with containment materials. Preparation of a final report covering all of the ${ }^{90} \mathrm{SrF}_{2}$ compatibility studies is now under way.

\section{TASK 3 - CAPSULE QUALIFICATION AND LICENSING}

Charpy Impact Energy of Hastelloy S and Hastelloy $\mathrm{C}-4$

Hastelloy $\mathrm{S}^{\circledR}$ and Hastelloy $\mathrm{C}-4{ }^{\circledR}$ Charpy V-NotCh (CVN) specimens were heated in air or vacuum at $600^{\circ}$ to $800^{\circ} \mathrm{C}$ for up to $10,000 \mathrm{~h}$ and then impact-tested at room temperature. The objective of the study was to determine if oxidation of the two alloys would have any effect on the impact energy of the CVN specimens.

The CVN specimens were subsize (0.098-in.-thick $\times 0.394-i n$.-wide) and had been fabricated in accordance with ASTM Specification E23-72 (Anon. 1978). The specimens were cut from 0.125-in. solution heat-treated alloy sheet and were oriented with the notch parallel to the

(B) Cabot Corporation, Kokomo, Indiana. 
rolling direction and perpendicular to the surface of the sheet. Subsize specimens were used to emphasize the potential effects of oxidation on the impact energy of the CVN specimens.

oxidation of the CVN specimens was determined by weighing the specimens before and after the heating cycle. Subsurface attack of the metal due to oxidation was determined by metallographic examination of some specimens after they had been impact-tested. Table 1 summarizes the oxidation data obtained with the CVN specimens. If the weight-gain data presented in Table 1 are plotted as $\Delta w^{2}\left(\mathrm{mg}^{2} / \mathrm{cm}^{4}\right)$ against time $(\mathrm{h})$, the results shown in Figures 1 and 2 are obtained. The straight lines shown in the figures represent the parabolic rate equations for the oxidation of Hastelloy S and Hastelloy C-4 in air at $600^{\circ}$ to $800^{\circ} \mathrm{C}$ that were previously reported (Fullam 1980a). The results show that oxidation of the CVN specimens adhered to the parabolic rate equations for exposures up to $5000 \mathrm{~h}$, but longer exposures led to negative deviations from the parabolic relationships. This agrees with the results obtained in the earlier study.

Subsurface attack of the CVN specimens due to oxidation was estimated from photomicrographs of the failed specimens and the results obtained are presented in Table 2. The erratic nature of the data makes it difficult to determine what type of rate equation applies to the subsurface attack. Similar erratic behavior was also observed in the earlier oxidation studies. At $800^{\circ} \mathrm{C}$, subsurface attack of the Hastelloy $\mathrm{S}$ and Hastelloy $\mathrm{C}-4$ specimens after 10,000 hours exposure was 50 and $55 \mu \mathrm{m}$, respectively, which meant that 5 to $6 \%$ of the cross-sectional area below the notch of the CVN specimens was affected by the attack.

The CVN specimens were impact-tested at room temperature and the results obtained are presented in Table 3 and Figures 3 and 4 . A cursory examination of the data indicates that the specimens heated in air at $700^{\circ}$ and $800^{\circ} \mathrm{C}$ exhibited a slightly higher room-temperature Charpy impact energy than did the control specimens heated in vacuum. However, statistical analysis of data shows that there are no significant differences between the results obtained with the oxidized specimens and the control specimens heated in vacuum. This means that subsurface attack of Hastelloy S and Hastelloy C-4 due to oxidation (which affected up to 5 to $6 \%$ of the cross-sectional area of CVN specimens) had no significant effect on their impact energies.

TABLE 1. 0xidation of Hastelloy S and Hastelloy C-4 in Air

\begin{tabular}{|c|c|c|c|c|c|c|}
\hline \multirow[b]{3}{*}{ Time, $h$} & \multicolumn{6}{|c|}{ Average Specimen Weight Gain ${ }^{(a)} \Delta \mathrm{w}, \mathrm{mg} / \mathrm{cm}^{2}$} \\
\hline & \multicolumn{3}{|c|}{ Hastelloy S } & \multicolumn{3}{|c|}{ Haste110y C-4 } \\
\hline & $600^{\circ} \mathrm{C}$ & $700^{\circ} \mathrm{C}$ & $800^{\circ} \mathrm{C}$ & $600^{\circ} \mathrm{C}$ & $700^{\circ} \mathrm{C}$ & $800^{\circ} \mathrm{C}$ \\
\hline 1,000 & 0.074 & 0.182 & 0.281 & & & \\
\hline 2,500 & 0.099 & 0.245 & 0.406 & 0.449 & 0.552 & 0.694 \\
\hline 5,000 & 0.109 & 0.342 & 0.550 & 0.505 & 0.617 & 0.758 \\
\hline 7,500 & 0.111 & 0.363 & 0.598 & 0.520 & 0.620 & 0.869 \\
\hline 10,000 & 0.105 & 0.362 & 0.658 & 0.501 & 0.679 & 0.887 \\
\hline
\end{tabular}

(a) Average for duplicate specimens. 


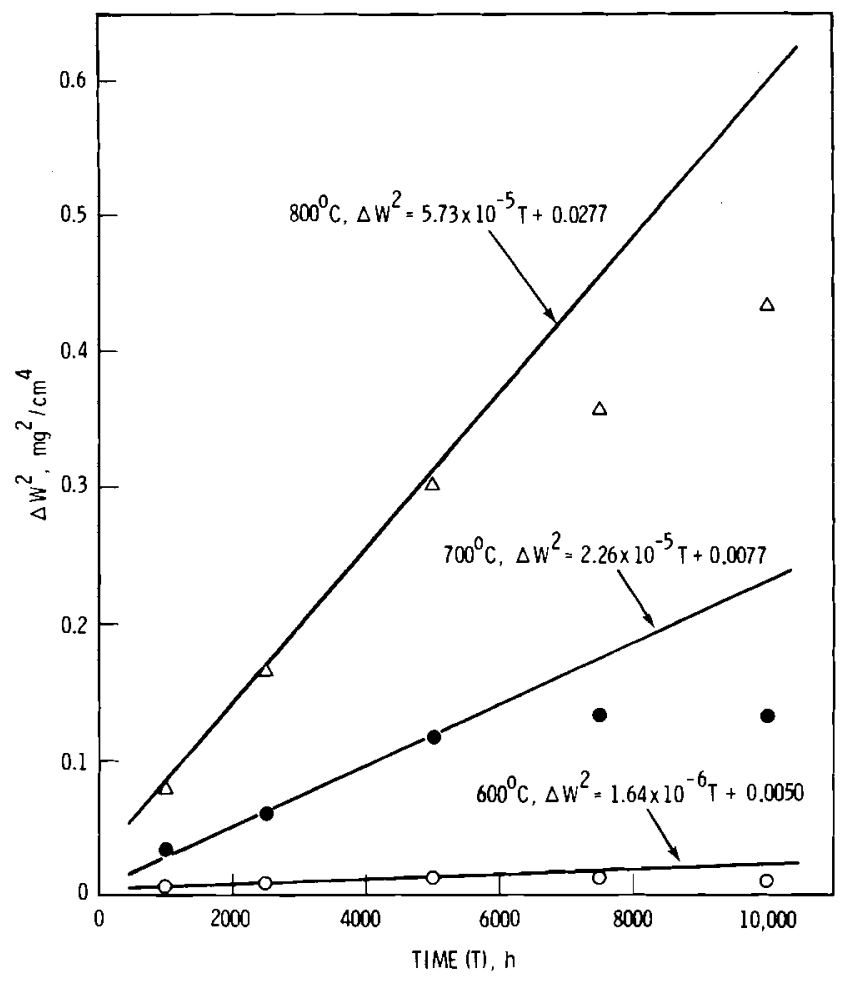

FIGURE 1. The Oxidation of Hastelloy $S$ in Air

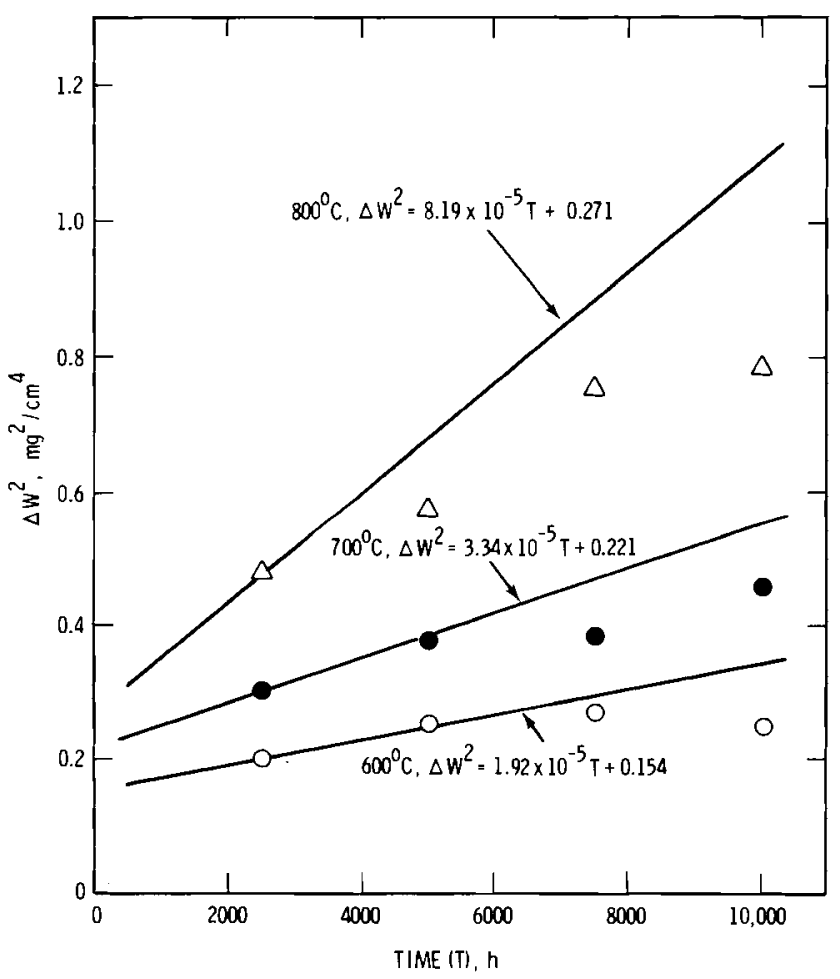

FIGURE 2. The 0xidation of Hastelloy C-4 in Air 
TABLE 2. Subsurface Attack of Hastelloy S and Hastelloy C-4 Specimens $0 x$ idized in Air at $600^{\circ}$ to $800^{\circ} \mathrm{C}$

\begin{tabular}{|c|c|c|c|}
\hline Temp., ${ }^{\circ} \mathrm{C}$ & Time, $h$ & $\begin{array}{l}\text { Depth of Metal } \\
\text { Hastelloy S }\end{array}$ & $\frac{\text { Affected, (a) } \mu \mathrm{m}}{\text { Hastelloy } \bar{C}-4}$ \\
\hline 600 & $\begin{array}{r}1,000 \\
2,500 \\
5,000 \\
10,000\end{array}$ & $\begin{array}{l}18 \\
20 \\
25\end{array}$ & $\begin{array}{l}15 \\
25 \\
20\end{array}$ \\
\hline 700 & $\begin{array}{r}1,000 \\
2,500 \\
5,000 \\
10,000\end{array}$ & $\begin{array}{l}20 \\
25 \\
20\end{array}$ & $\begin{array}{l}22 \\
32 \\
50\end{array}$ \\
\hline 800 & $\begin{array}{r}1,000 \\
2,500 \\
5,000 \\
10,000\end{array}$ & $\begin{array}{l}18 \\
38 \\
50\end{array}$ & $\begin{array}{l}25 \\
45 \\
55\end{array}$ \\
\hline
\end{tabular}

(a) Estimated from photomicrographs of oxidized specimens.

TABLE 3. The Room-Temperature Charpy Impact Energy of Hastelloy S and Hastelloy C-4 CVN Specimens Heated in Air or Vacuum

\begin{tabular}{|c|c|c|c|c|c|}
\hline \multirow[b]{3}{*}{ Temp., ${ }^{\circ} \mathrm{C}$} & \multirow[b]{3}{*}{ Time, $h$} & \multicolumn{4}{|c|}{ Charpy Impact Energy, ${ }^{(a)} \mathrm{ft}-1 \mathrm{~b}$} \\
\hline & & \multicolumn{2}{|c|}{ Hastelloy S } & \multicolumn{2}{|c|}{ Hastelloy C-4 } \\
\hline & & Vacuum & Air & Vacuum & Air \\
\hline \multicolumn{2}{|c|}{$[$ As-Received $(\mathrm{b})]$} & \multicolumn{2}{|c|}{$(14.0)$} & \multicolumn{2}{|c|}{$(29.5)$} \\
\hline 600 & $\begin{array}{r}1,000 \\
2,500 \\
5,000 \\
7,500 \\
10,000\end{array}$ & $\begin{array}{r}10.1 \\
8.7 \\
7.6 \\
6.5 \\
5.8\end{array}$ & $\begin{array}{l}9.8 \\
8.7 \\
7.2 \\
7.2 \\
6.2\end{array}$ & $\begin{array}{l}8.7 \\
8.4 \\
7.6 \\
8.0\end{array}$ & $\begin{array}{l}8.0 \\
8.0 \\
7.2 \\
7.2\end{array}$ \\
\hline 700 & $\begin{array}{r}1,000 \\
2,500 \\
5,000 \\
7,500 \\
10,000\end{array}$ & $\begin{array}{r}9.4 \\
10.5 \\
11.6 \\
8.7 \\
10.1\end{array}$ & $\begin{array}{l}10.9 \\
11.6 \\
10.9 \\
10.5 \\
10.1\end{array}$ & $\begin{array}{l}23.9 \\
19.5 \\
23.3 \\
23.8\end{array}$ & $\begin{array}{l}23.9 \\
22.5 \\
24.0 \\
25.0\end{array}$ \\
\hline 800 & $\begin{array}{r}1,000 \\
2,500 \\
5,000 \\
7,500 \\
10,000\end{array}$ & $\begin{array}{l}15.5 \\
15.5 \\
16.3 \\
15.5 \\
16.5\end{array}$ & $\begin{array}{l}16.3 \\
16.5 \\
16.5 \\
16.3 \\
17.0\end{array}$ & $\begin{array}{l}25.8 \\
29.0 \\
27.5 \\
26.8\end{array}$ & $\begin{array}{l}32.8 \\
28.5 \\
28.3 \\
28.0\end{array}$ \\
\hline
\end{tabular}

(a) Average value for duplicate specimens except for as-received values where six Hastelloy $\mathrm{S}$ and five Hastelloy $\mathrm{C}-4$ specimens were tested.

(b) Solution heat-treated alloy as received from the manufacturer.

The Hastelloy S and Hastelloy C-4 CVN specimens showed the greatest reduction in Charpy impact energy when aged at $600^{\circ} \mathrm{C}$; higher aging temperatures had less effect on the impact energy of the two alloys. The Hastelloy $\mathrm{S}$ specimens aged at $800^{\circ} \mathrm{C}$ actually showed an 

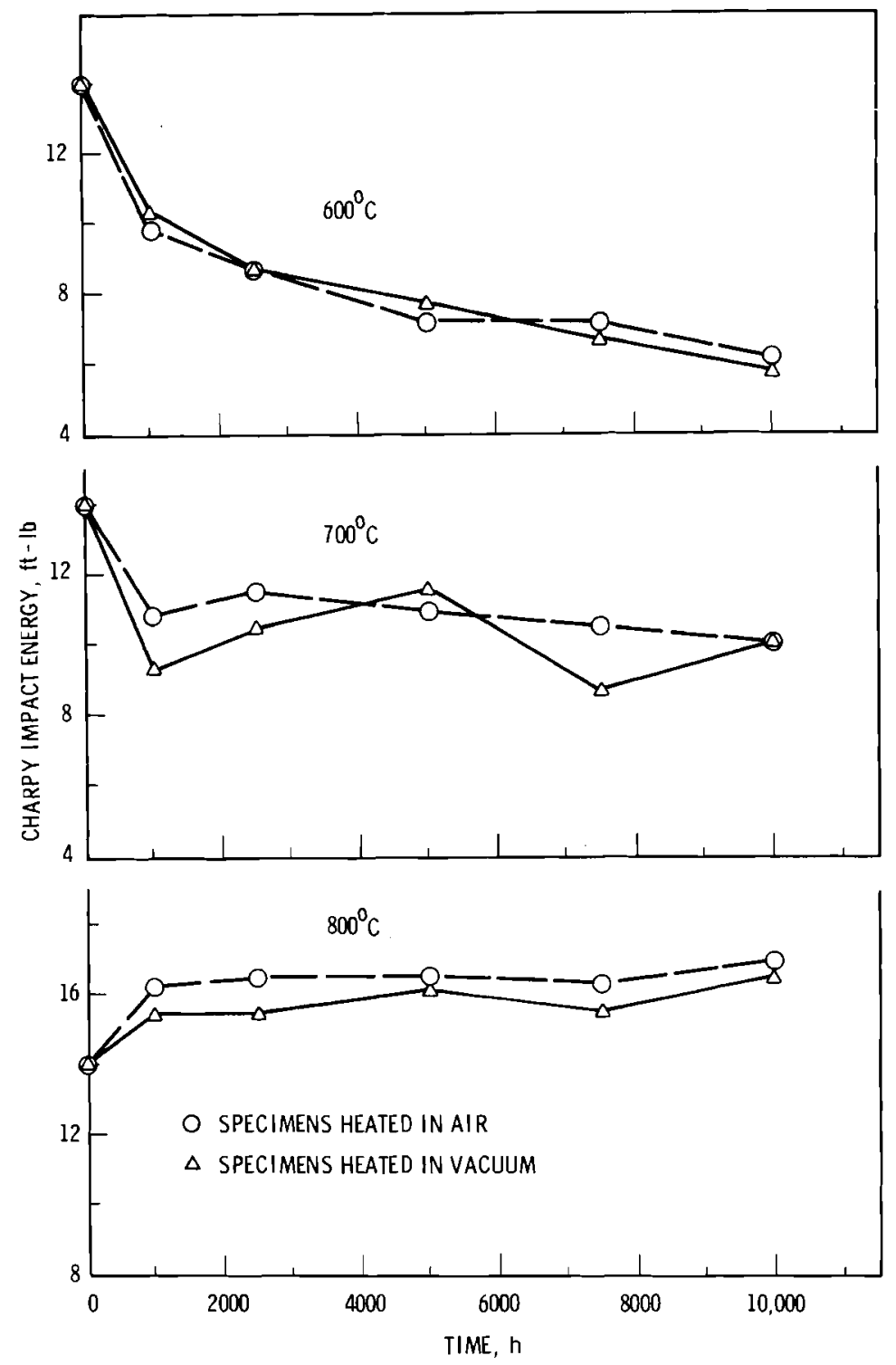

FIGURE 3. The Room-Temperature Charpy Impact Energy of Hastelloy S Specimens Heated in Air or Vacuum

increase in Charpy impact energy as compared to the solution heat-treated alloy. These results differ from data reported by Cabot Corp., which showed that both Hastelloy S and Hastelloy C-4 suffered the greatest reduction in Charpy impact energy when aged at about $760^{\circ} \mathrm{C}$ (Matthews 1976). Reasons for the differences in the two sets of data were not determined, but they may be due to differences in specimen size (the Cabot study used full-size CVN specimens) and/or to minor changes in the compositions of the different heats of alloys used in the two studies. 

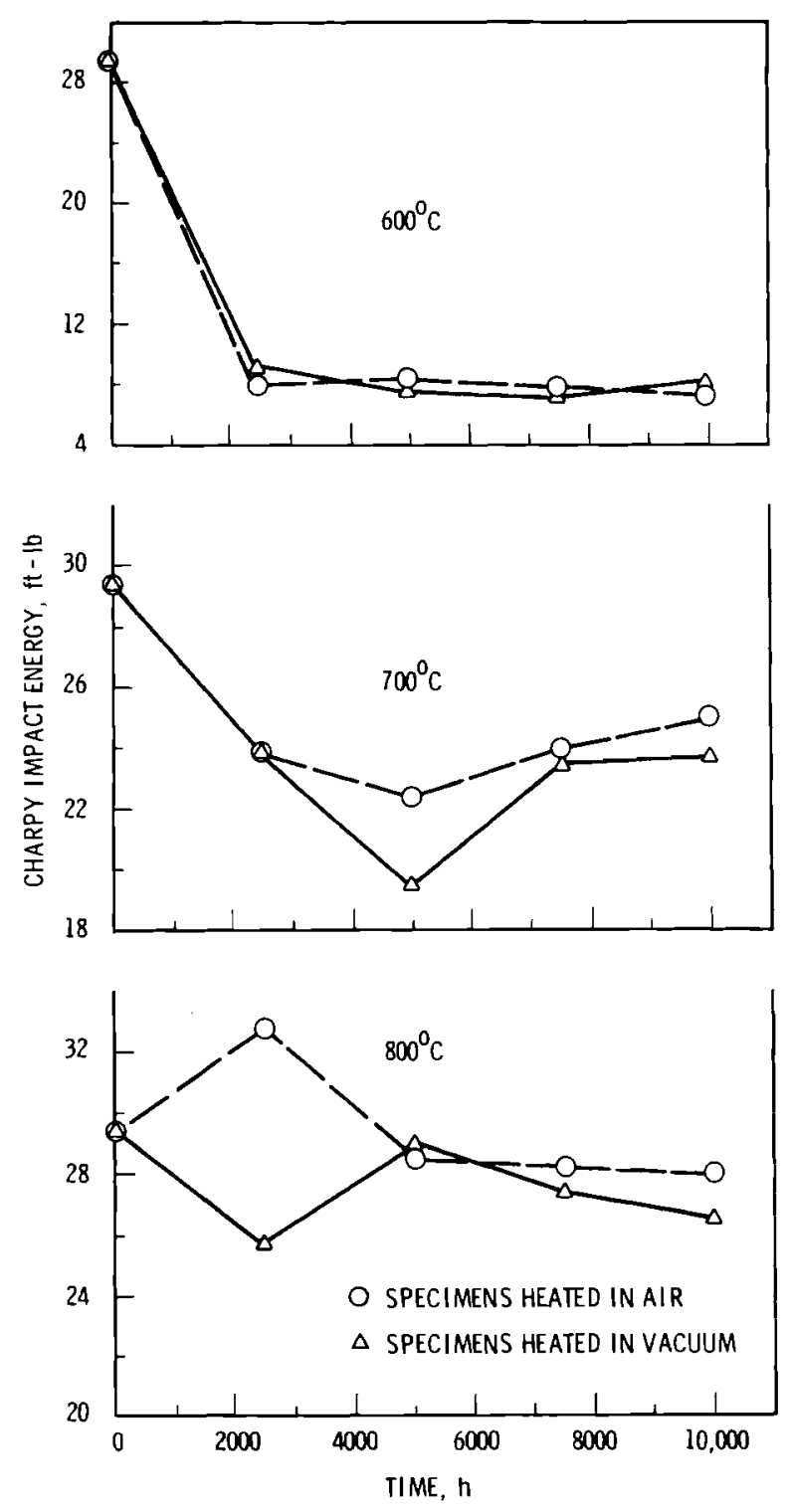

FIGURE 4. The Room-Temperature Charpy Impact Energy of Hastelloy C-4 Specimens Heated in Air or Vacuum

\section{Capsule Testing}

Qualification testing of the Hastelloy S and Hastelloy C-4 prototype outer capsules in the as-fabricated condition was completed. Each of the eight capsules was subjected to one primary qualification test and four secondary qualification tests, as outlined in the previous quarterly report (Fullam 1980b). Each capsule passed all of the tests without difficulty.

The two capsules subjected to the impact (drop) test--each of which contained a Hastelloy $\mathrm{C}-276^{\circledR}$ inner capsule filled with $\mathrm{SrF}_{2} 2^{- \text {did }}$ show some distortion at the weld area but

(8) Cabot Corporation, Kokomo, Indiana. 


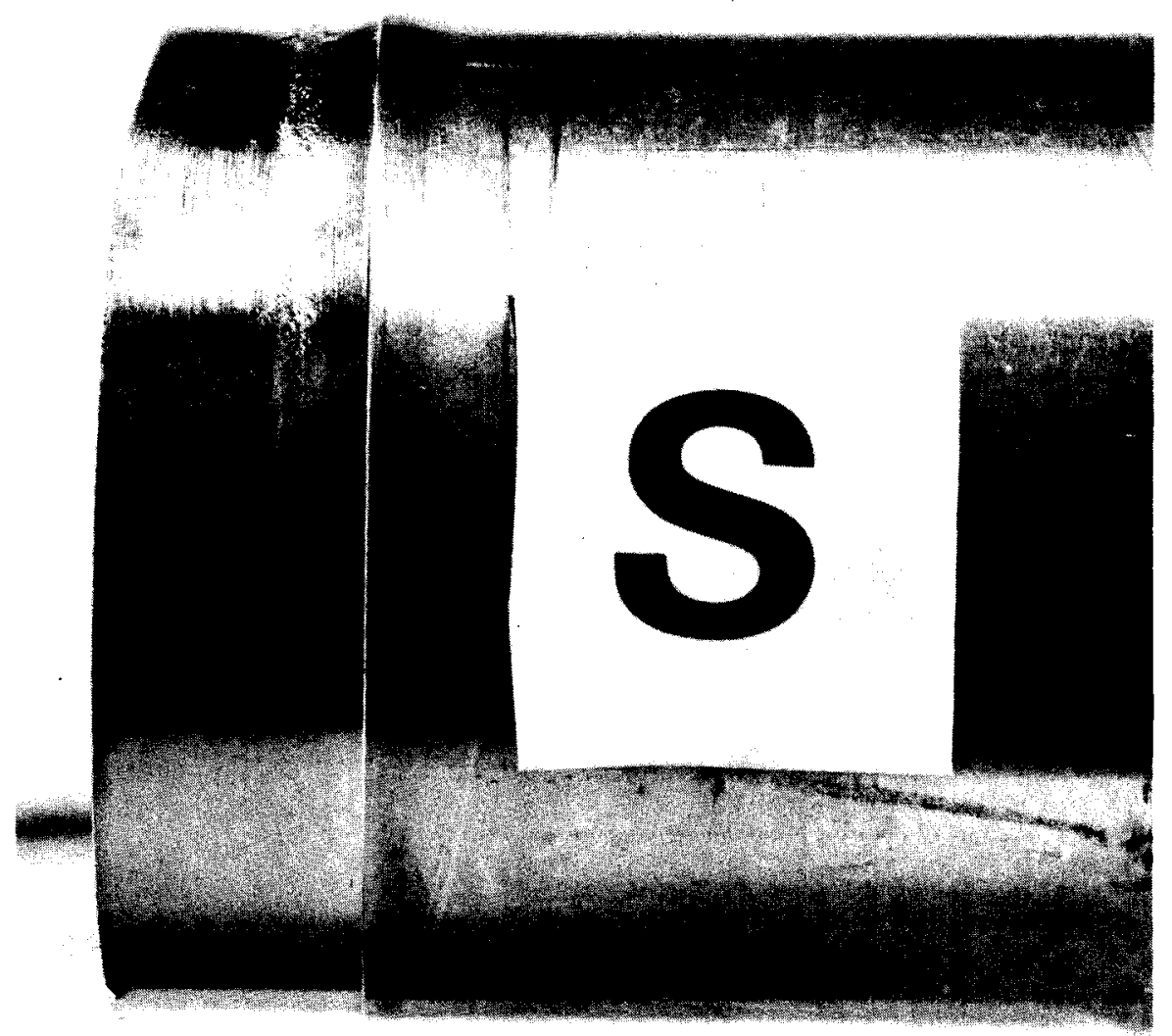

FIGURE 5. Distortion of the As-Fabricated Hastelloy S Prototype Outer Capsule Resulting from the Impact Test

did not leak. Figures 5 and 6 show the two capsules after the impact test and the distortion resulting from the drop is readily apparent. After qualification testing of the two capsules was completed, they were sectioned and the inner capsules were removed. The impacted ends of the capsules were then sectioned and subjected to metallographic examination to determine what effect the impact and resulting distortion had on the seal weld. The section from the Hastelloy $S$ capsule is shown in Figure 7. The impact produced an outward bowing of the capsule wall and some distortion of the interlocking closure. Greater magnifications of the weld area are shown in Figure 8 . The micrographs show that complete penetration was attained with the seal weld. They also show what is possibly the beginning of a crack at the inner edge of the weld zone. Additional examination of the end cap is under way to determine if cracking had started.

Figure 9 shows the impacted end of the Hastelloy C-4 capsule. The micrograph shows a complete-penetration seal weld and bowing of the capsule wall similar to that observed with the Hastelloy S capsuTe. Micrographs of the weld area (Figure 10) show what appears to be the beginning of a crack at the inner surface of the weld zone. 


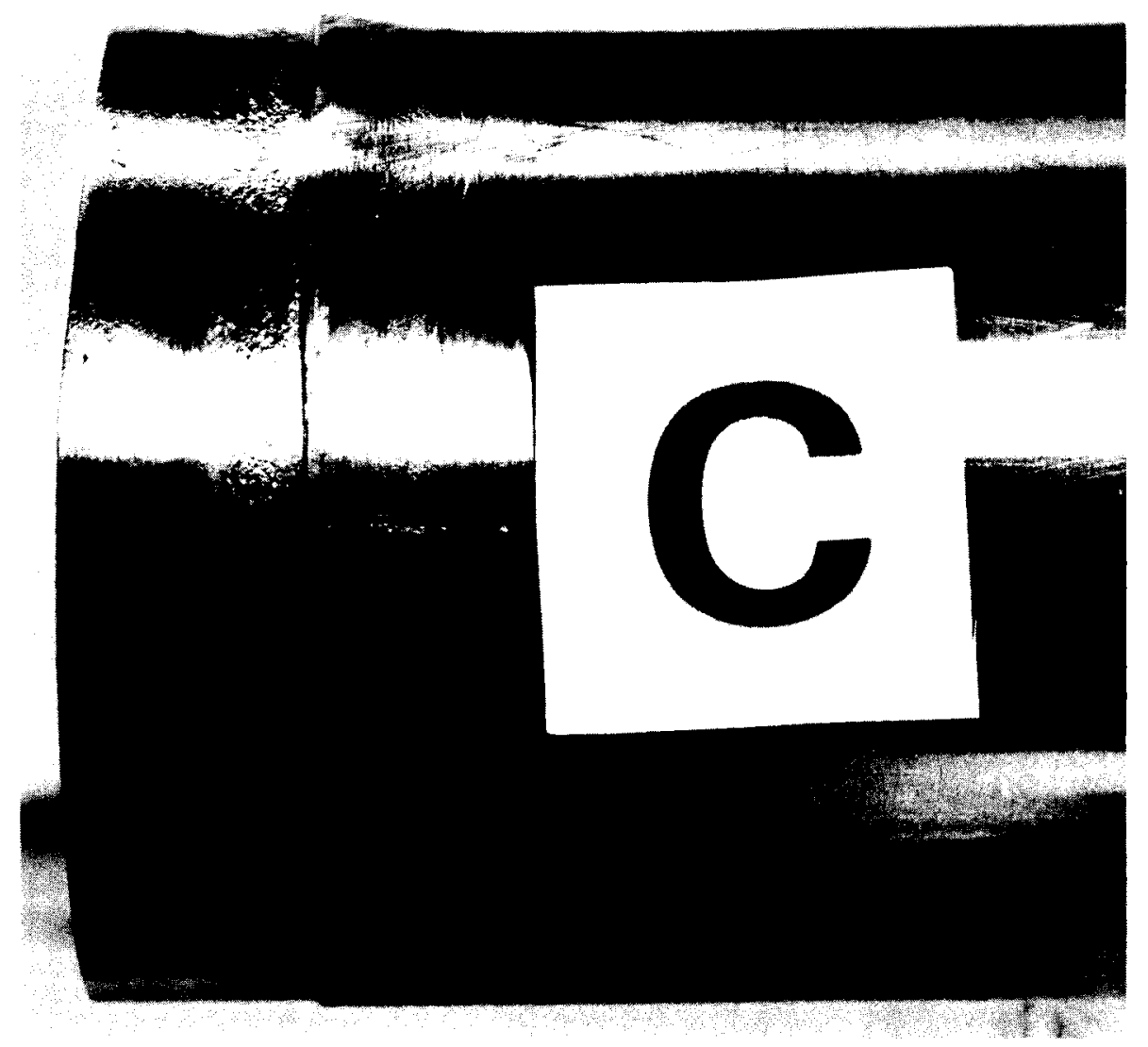

FIGURE 6. Distortion of the As-Fabricated Hastelloy C-4 Prototype Outer Capsule Resulting from the Impact Test

After the required qualification testing of the as-fabricated outer capsules was completed, several capsules that did not contain inner capsules were subjected to additional testing. Two of the capsules were subjected to additional hydrostatic pressure tests. The Hastelloy $S$ capsule was pressurized to 24,000 psi--the limit of the autoclave--and showed only a slight distortion. The maximum and minimum dimensions of the capsule at the point of maximum distortion were $3.423 \mathrm{in}$. and $3.306 \mathrm{in.,}$ respectively. The Hastelloy C-4 capsule collapsed at 20,750 psi. Figure 11 shows the capsule after pressurization, while Figure 12 gives the dimensions of the collapsed capsule at various locations. Both capsules passed the helium leak check of $1 \times 10^{-8} \mathrm{cc} / \mathrm{s}$ (STP) after pressurization.

Two other as-fabricated capsules were subjected to increased percussion tests. The test was identical to the original percussion test except that the impact energy was raised from 7 to $20 \mathrm{~kg}-\mathrm{m}$. Each capsule was impacted at the same five locations as in the original test. Both the Hastelloy $S$ and Hastelloy $C-4$ capsules passed the additional percussion test without difficulty. 


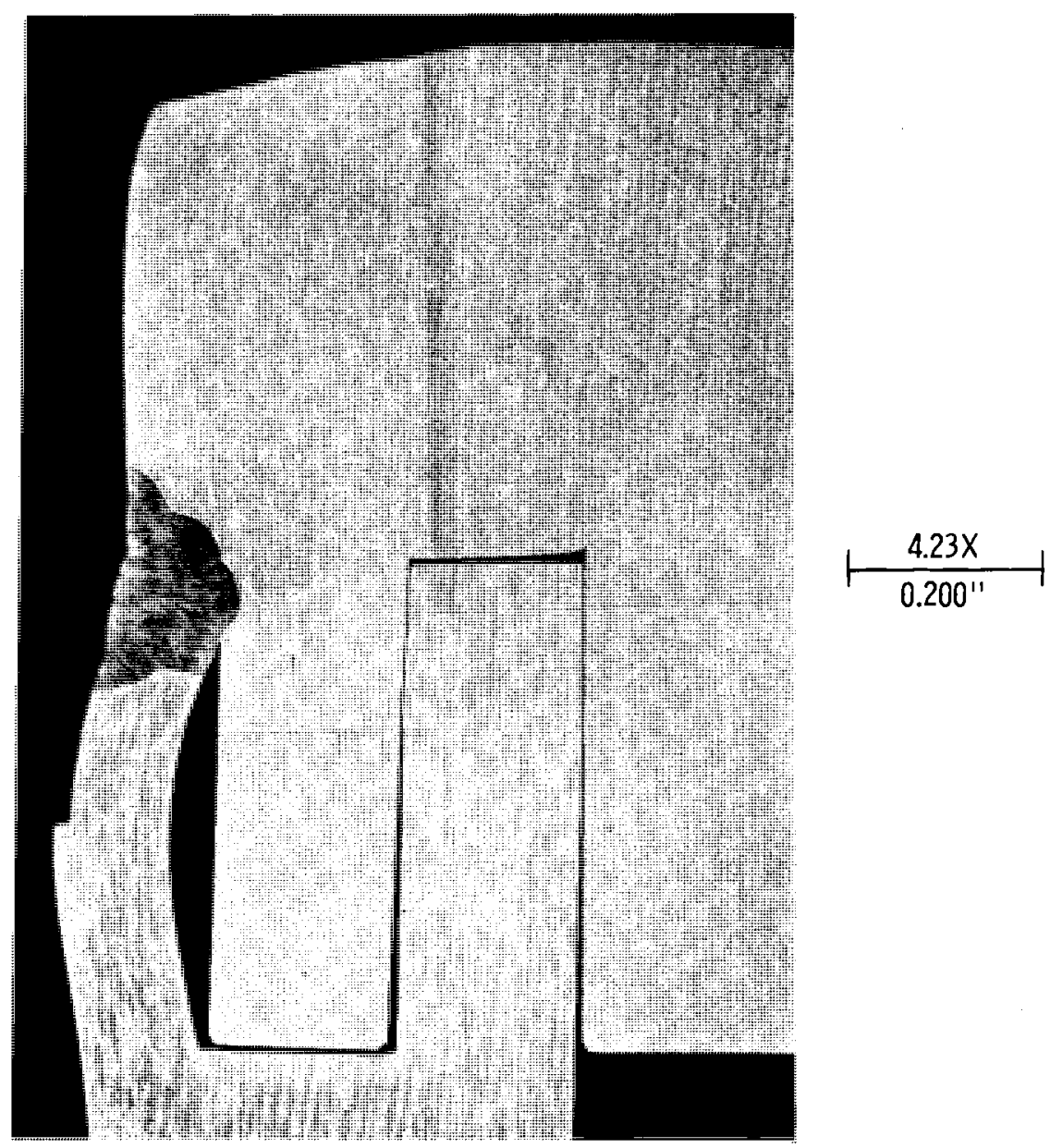

FIGURE 7. End Cap of the Hastelloy S Capsule After the Impact Test Showing the Distortion of the Capsule Wall

The two Hastelloy $\mathrm{C}-276$ inner capsules that were removed from the outer capsules after the impact (drop) tests were completed were also subjected to additional testing. One capsule was subjected to the impact test by itself and passed the test without difficulty and with very little distortion of the end cap. The other capsule was first subjected to the percussion test, which it passed without difficulty, and was then subjected to the hydrostatic pressure test, during which it collapsed at a pressure of $9700 \mathrm{psi}$ (see Figure 13). Even after collapsing, however, the capsule did not leak. 

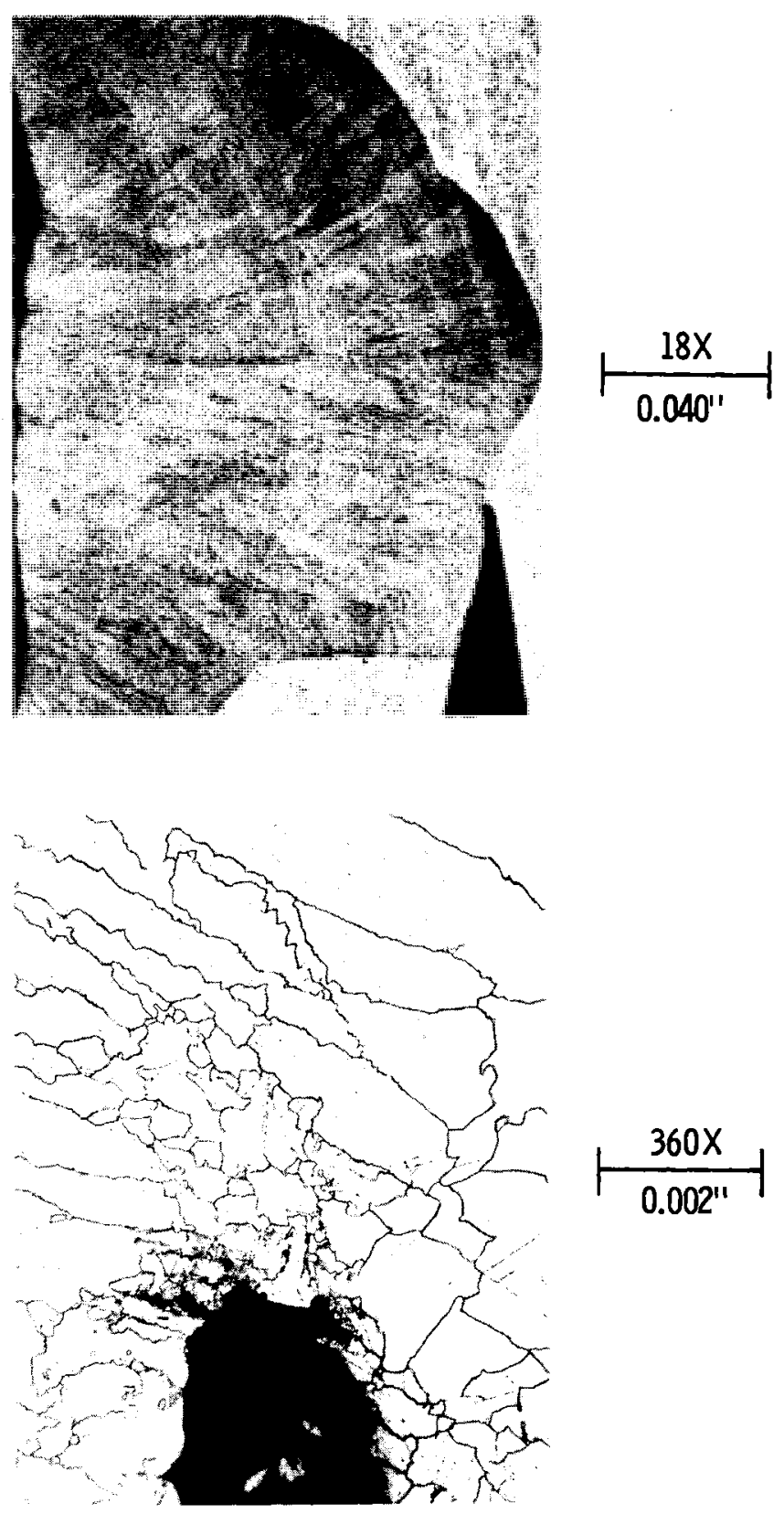

FIGURE 8. Weld Area of the Impacted Hastelloy S Capsule 


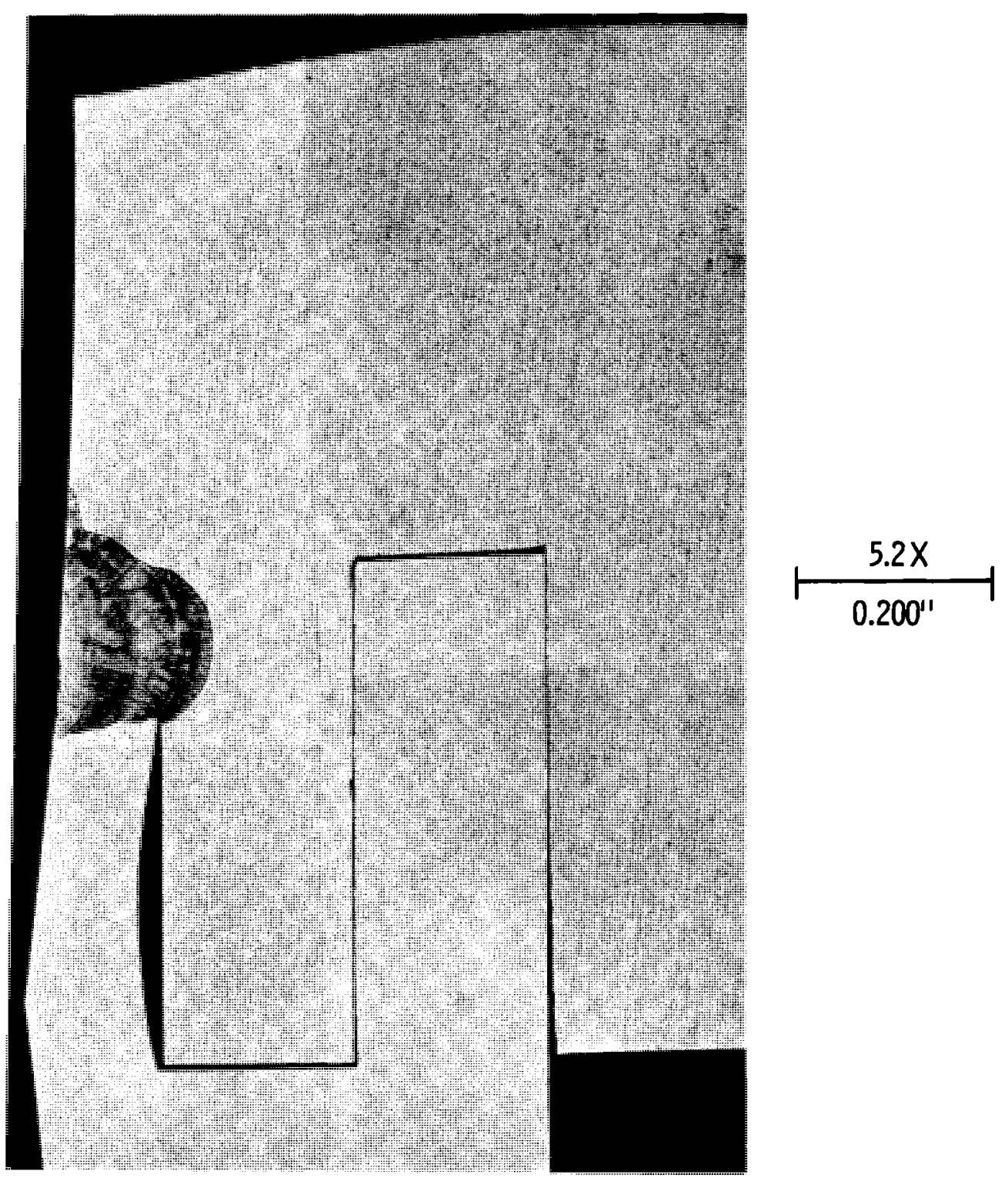

FIGURE 9. End Cap of the Hastelloy C-4 Capsule After the Impact Test Showing the Distortion of the Capsule Wall 

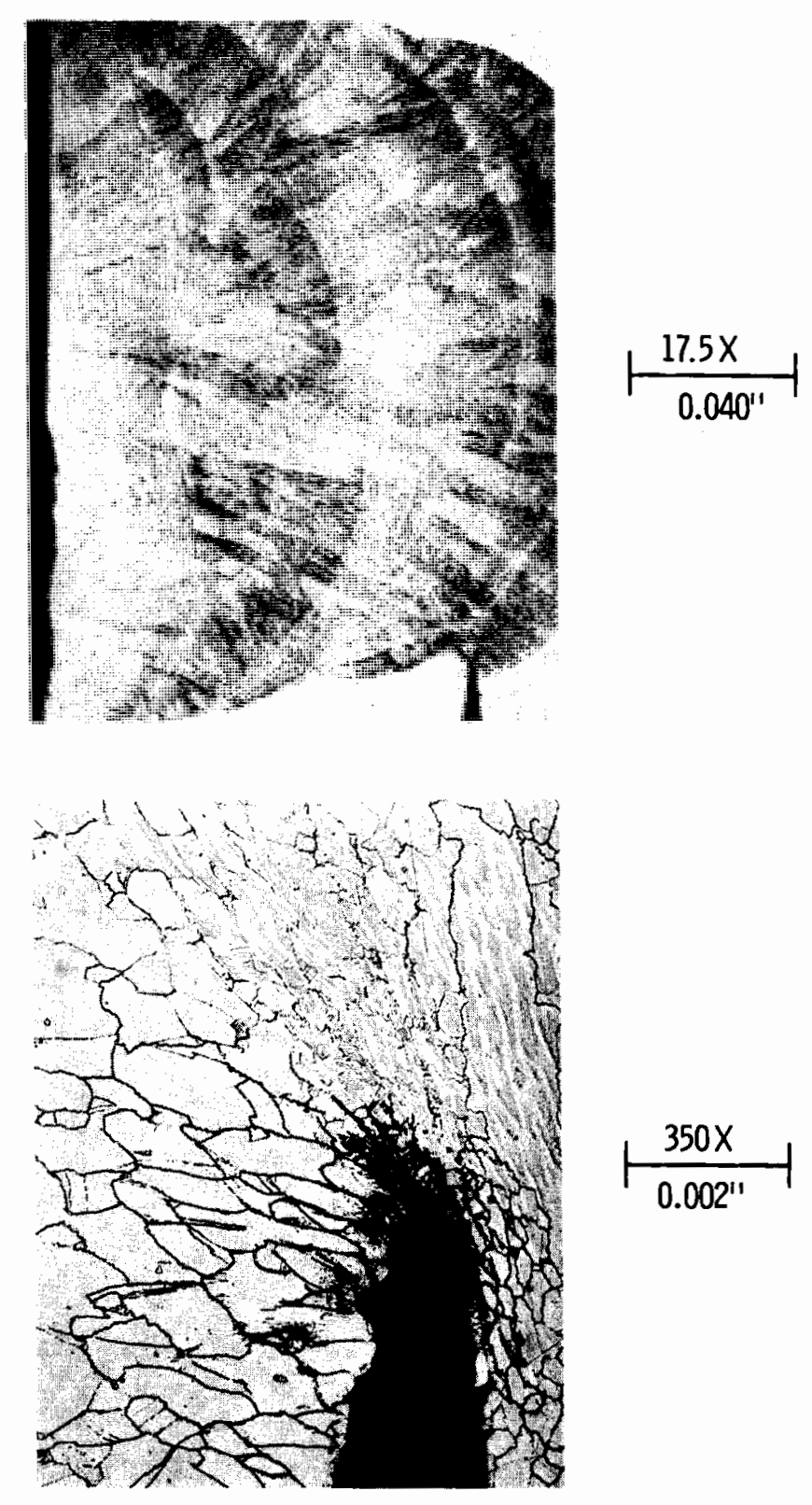

FIGURE 10. Weld Area of the Impacted Hastelloy C-4 Capsule 


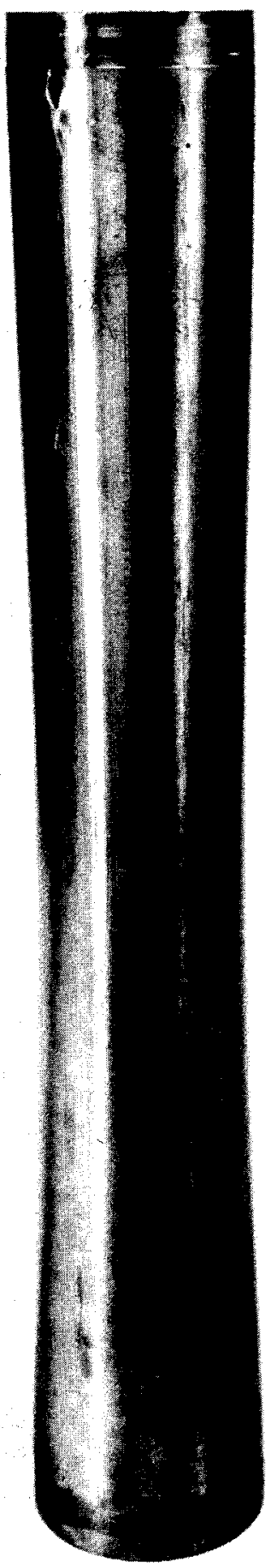

FIGURE 11. As-Fabricated Hastelloy C-4 Outer Capsule After Being Subjected to an External Hydrostatic Pressure of 20,700 psi 


\begin{tabular}{|c|c|c|}
\hline MINIMUM DIA., in. & MAXIMUM DIA., in. & \\
\hline 3.366 & 3.385 & $1^{\prime \prime}$ \\
\hline 3.294 & 3.412 & $2^{\prime \prime}$ \\
\hline 3.197 & 3.474 & $2^{\prime \prime}$ \\
\hline 3.085 & 3.542 & $2^{\prime \prime}$ \\
\hline 2.969 & 3.607 & $2^{\prime \prime}$ \\
\hline 2.937 & 3.628 & \\
\hline 2.957 & 3.624 & \\
\hline 3.045 & 3.583 & $2^{\prime \prime}$ \\
\hline 3.176 & 3.485 & $2^{\prime \prime}$ \\
\hline 3.314 & 3.388 & $2^{\prime \prime}$ \\
\hline 3.361 & 3.383 & $2 "$ \\
\hline & & $1^{\prime \prime}$ \\
\hline
\end{tabular}

FIGURE 12. Dimensions of the As-Fabricated Hastelloy C-4 Capsule After Being Subjected to an External Hydrostatic Pressure of $20,750 \mathrm{psi}$ 


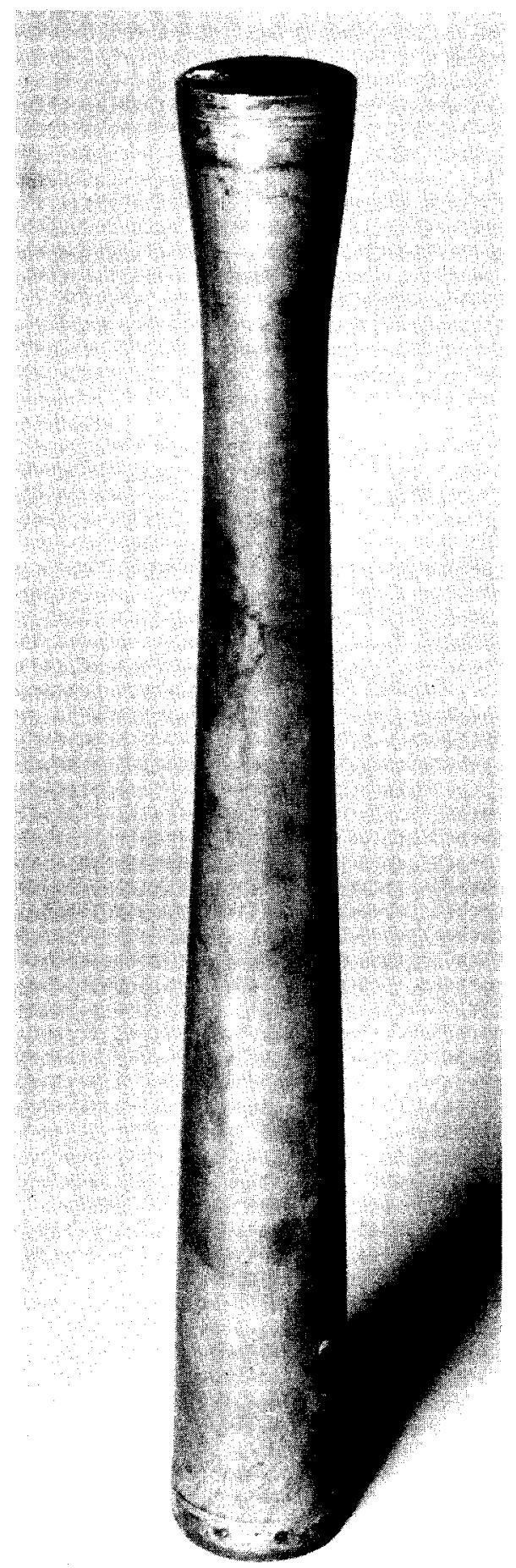

FIGURE 13. The Hastelloy C-276 Inner Capsule After Being Subjected to An External Hydrostatic Pressure of 9700 psi 


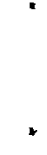




\section{REFERENCES}

Anon. 1978. Annual Book of ASTM Standards - Part 10. American Society for Testing and Materials.

Fullam, H. T. 1980a. Air 0xidation and Seawater Corrosion of Hastelloy S and Haste 1loy C-4. PNL-3344, Pacific Northwest Laboratory, Richland, Washington.

Ful1am, H. T. 1980b. Quarterly Report on the Strontium Heat Source Development Program, Advanced Nuclear Systems and Projects Division for Apri1-June 1980. PNL-1845-47, Pacific Northwest Laboratory, Richland, Washington.

Matthews, S. J. 1976. Thermal Stability of Solid Solution Strengthened High Performance

Alloys. Report No. $89 \overline{79}$, Stellite Division - Cabot Corp., Kokomo, Indiana. 


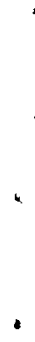


No. of

Copies

OFFSITE

A. A. Churm

DOE Patent Division

9800 S. Cass Avenue

Argonne, IL 60439

N. Goldenberg

DOE Advanced Nuclear Systems and Projects Division

Washington, DC 20545

G. L. Bennett

DOE Advanced Nuclear Systems and Projects Division

Washington, DC 20545

T. J. Holleman

DOE Advanced Nuc lear Systems and Projects Division

Washington, DC 20545

A. P. Litman

DOE Advanced Nuclear Systems and Projects Division

Washington, DC 20545

J. J. Lomb ardo

DOE Advanced Nuclear Systems and Projects Division

Washington, DC 20545

3 W. C. Remini

DOE Advanced Nuclear Systems and Projects Division

Washington, DC 20545

B. J. Rock

DOE Advanced Nuclear Systems and Projects Division

Washington, DC 20545

N. R. Thielke

DOE Advanced Nuclear Systems and Projects Division

Washington, DC 20545

J. M. Maddox

DOE

E201

Washington, DC 20545

C. A. Cooley

DOE Waste Management Division

Washington, DC 20545
No. of

Copies

D. C. Davis, Jr.

DOE Oak Ridge Operations Office

P.0. Box E

Oak Ridge, TN 37830

W. T. Goldston

DOE Savannah River Operations Office

P.0. Box A

Aiken, SC 29801

27 DOE Technical Information Center

L. J. Jardine

Argonne National Laboratory

9700 South Cass Avenue

Argonne, IL 60439

W. R. Pardue

Battelle Columbus Laboratories

$505 \mathrm{King}$ Avenue

Columbus, $\mathrm{OH} 43201$

R. T. Huntoon

E. I. duPont deNemours and Company

Savannah River Laboratory

Aiken, SC 29801

E. H. Cooke-Yarborough

Electronics and Applied Physics

Division

Building 347.3, AERE Harwell

Oxfordshire OX11 ORA

GREAT BRITAIN

H. C. Carney

General Atomic Company

P.0. Box 81601

San Diego, CA 92138

S. E. Bronisz

Los Alamos Scientific Laboratory

P.0. Box 1663

Los Alamos, NM 87544

R. A. Kent

Los Alamos Scientific Laboratory P.0. Box 1663

Los Alamos, NM 87544

R. N. R. Mulford

Los Alamos Scientific Laboratory

P. 0. Box 1663

Los Alamos, NM 87544 
No. of

Copies

W. T. Cave

Monsanto Research Corporation

Mount Laboratory (DOE)

Nuclear Operations

P.0. Box 32

Miamisburg, $\mathrm{OH} 45342$

R. Dewitt

Monsanto Research Corporation

Mount Laboratory (DOE)

Nuc lear Operations

P.0. Box 32

Miamisburg, $\mathrm{OH} 45342$

Department of the Army

Headquarters, U.S. Army

Facilities Engineering Support Agency

Ford Belvoir, VA 22060

H. H. Musselman, Tech. Dir.

Officer in Charge

Lt. J. H. Vogt

Naval Nuclear Power Unit

Code 70

Port Hueneme, CA 93043

H. V. Weiss

Code 631

Naval Ocean Systems Center

San Diego, CA 92152

2 A. A. Arcuni

Naval Facilities Engineering Command Office of Special Assistant Nuclear Programs (04N)

200 Stovall Street

Alexandria, VA 22332

K. W. Haff

Oak Ridge National Laboratory

Oak Ridge, TN 37830

J. Hammond

Oak Ridge National Laboratory

Oak Ridge, TN 37830

J. R. Keiser

Oak Ridge National Laboratory

Oak Ridge, TN 37830

E. Lamb

Oak Ridge National Laboratory

Oak Ridge, TN 37830

A. C. Schaffhauser

Oak Ridge National Laboratory

Oak Ridge, TN 37830
No. of

Copies

P. Dick

Teledyne Energy Systems

110 W. Timonium Road

Timonium, MD 21093

R. Hannah

Teledyne Energy Systems

$110 \mathrm{~W}$. Timonium Road

Timonium, MD 21093

W. A. McDonald

Teledyne Energy Systems

110 W. Timonium Road

Timonium, MD 21093

P. Vogelberger

Teledyne Energy Systems

$110 \mathrm{~W}$. Timonium Road

Timonium, MD 21093

C. C. Silverstein

Westinghouse Astronuclear Laboratory

P.0. Box 10864

Pittsburgh, PA 15236

\section{ONSITE}

4 DOE Richland Operations

D. Bogon

R. E. Gerton

H. A. House

H. E. Ransom

8 Rockwell Hanford Operations

L. I. Brecke

H. H. Hopk ins

J. D. Kaser

E. J. Kosiancic

T. H. May

D. Ramey

J. P. Sloughter

C. R. Stroup

22 Pacific Northwest Laboratory

D. G. Atteridge

S. D. Dahlgren

H. T. Fullam (3)

M. H. Henry (2)

G. B. Long

R. E. Nightingale

N. J. 01 son

L. D. Perrigo

A. M. Platt

W. E. Sande

F. A. Simonen

H. H. Van Tuyl

Technical Files (5)

Publishing Coordination EI (2) 